\title{
The Influence of Corporate Image and Promotion on Customer Satisfaction towards Loyalty
}

\author{
Aditya Dwi Irawan', Kandi Sofia Senastri Dahlan ${ }^{2}$, Rustono Farady Marta ${ }^{3}$, \\ Lusi Lian Piantari ${ }^{4}$, Maichel Chinmi ${ }^{5}$ \\ Universitas Bunda Mulia, Jln. Lodan Raya No. 2, North Jakarta, 14430, Jakarta, Indonesia ${ }^{2,3}$, Universitas \\ Bunda Mulia, Jalur Sutera Barat Kav. 7-9, Tangerang, Indonesia ${ }^{1,5}$ Al-Azhar University Masjid Agung \\ Al-Azhar, Jl. Sisingamangaraja No.2, Jakarta, Indonesia ${ }^{4}$ \\ aditya.d.irawan@gmail.com ${ }^{1}$, kdahlan@bundamulia.ac.id²,rmarta@bundamulia.ac.id ${ }^{3}$, \\ lusi_lian@uai.ac.id ${ }^{4}$, mchinmi@bundamulia.ac.id ${ }^{5}$
}

\begin{abstract}
This study analyzes of the effect of image and promotion on customer loyalty mediated by customer satisfaction (a study of Alfamart minimarket customers in Tangerang). The research problem proposed refers to some previous research and the existence of a research gap from previous research. Five hypotheses have been formulated and a model has been developed to answer this research problem. The sampling technique is the quota sampling method. Respondents from this study amounted to 252 respondents, where the respondents are Alfamart minimarket customers in Tangerang, who have spent at least 2 times in the last 3 months. The analytical tool used is Statistical Product and Service Solutions (SPSS). The analysis results of this study's data indicate the model and the results of the study can be well received. The results of this study prove that the image and promotion of positive and significant effect on customer loyalty show that customer satisfaction is proven to positively moderate the effect of independent variables on the dependent variable in this study.
\end{abstract}

Keywords: Corporate image, promotion, customer satisfaction, Customer loyalty, Alfamart

\section{Introduction}

The minimarket industry has changed significantly, becoming a very challenging and competitive industry[1]. Minimarkets face considerable challenges in understanding consumer behavior, given changes in consumption patterns and trends, shifts in consumer attitudes, interests and lifestyles, demand for selected products. Consumer behavior is the core of the minimarket industry.

One of them is Alfamart minimarket. Alfamart minimarket has a problem in customer loyalty because of the many similarities in the mechanism of product sales in various minimarkets, such as reduced prices or discounts.

Also, the phenomenon that occurs in Alfamart is that not all customers who are registered as Alfamart members shop actively at Alfamart. This condition shows that not all Alfamart members are loyal to continue shopping at Alfamart. The percentage of active Alfamart members who are loyal and actively shop only around $50.97 \%$ of the total $10,168,875$ registered members.

The competition that occurs makes minimarket companies must work hard to compete and keep their customers [2]. One of them is by increasing the run's promotion mechanism, which is expected to increase product sales promoted by the minimarket. 
Ramanathan et al.[3] is a particular relevance in analyzing problems referring to the retail industry because chains in the retail sector are the most competitive, identified by the most diverse buying habits. Grewal et al. said [4] challenges in this sector are authentic, both from a global scale to the store level, focusing on maximizing the variety of goods sold, because this will later influence consumer choices.

\section{Literature Review}

\subsection{Corporate Image}

Corporate image, in this case a corporate brand, is an intangible asset that is very valuable, difficult to replicate, and can help achievefinancial performance [5], [6]. Corporate brands and product brands play different roles in an organization [7]. The final benefit of a corporate brand is to provide a value proposition or customer relationship based on organizational associations to give credibility to other brands (expertise, trustworthiness, and like), and to be a vehicle for clarifying and crystallizing organizational culture and values within the organization.At the same time, some researchers use image and reputation as a substitute. Reputation as an award in the company's long-term perspective, because there is a possibility that the initial study on the company's image using the concept of reputation they have done now.A reputation within a company can act as a signal that summarizes its past behavior that can be used to predict future actions. The general assumption in the branding literature is that a favorable brand image will have a positive impact on consumer behavior towards the brand, such as the opportunity to determine premium prices, more and loyal buyers of the word of mouth information [5], [8].

Blut et al.[9] describes imagery with an assessment of personal experiences, word of mouth, advertisements and promotions. Imagery is a multidimensional construction or set of perceptions carried out by stakeholders. They emphasized the critical role of employees as external communicators which has an impact on improving the company's image. The company's image is described as an intangible emotional association with psychological conditions that develop into feelings and attitudes [10]. Besides, the image can be influenced by consumers as recipients of knowledge, attitudes and behaviors towards an organization. at a certain point, the company's image consists of elements that go beyond individual perceptions.

\subsection{Promotion}

Promotion is widespread for a variety of reasons. among others, it can have a substantial increase in sales, maintain brand sales, maintain prices and fight competitors [11]. Minimarkets run price promotions to signal their buyers that the prices of the goods they sell are quite competitive.Also, promotions are carried out to attract buyers who do not usually buy. Minimarket also thinks that price promotion can encourage someone to try a new brand, hope they like it and promote repurchase later even if there is no promotion on regular price [12]

\subsection{Customer Satisfaction}

Customer satisfaction has three central positions.[13] First, customer satisfaction has been identified as a concept resulting from service quality. In this causal relationship, satisfaction is 
described as consumption after evaluation of service quality. Second, some researchers argue that customer satisfaction is the antecedent of service quality. The third position, postulating both satisfaction and service quality is antecedent of others.

\subsection{Customer Loyalty}

The minimarket retail industry is in a more competitive condition than before. This competition makes many companies struggle to increase market share [14]. Minimarket companies use data-based customer relationship management (CRM) strategies such as tiered discounts, promotional campaigns, personalization, customization, and improved distribution channels to gain new customers. Even with such a sophisticated process, many minimarket companies find it challenging to survive in an aggressive business environment as it is today. For this reason, companies consider customer loyalty as the main source of competitive advantage. As a result, many minimarkets use loyalty programs to improve business, maintain and improve their relationships with customers[15].

The loyalty program has two main objectives: to increase revenue by increasing revenue ties, and to maintain the current customer base by strengthening ties with customers [16]. This market has become very competitive, because almost every company offers some form of the customer loyalty program.

The ultimate goal of most minimarkets is to have loyal customers. Loyalty can be the result of customer satisfaction [17]. In the previous study review, there was a positive relationship between satisfaction and repurchase. Therefore, it is likely that satisfied customers will be more loyal to their main store.

\section{Method}

This type of research used in this study is a quantitative research method. Quantitative research is a type of research that basically uses a deductive - inductive approach. This approach departs from a theoretical framework, the ideas of experts, and understanding of researchers based on their experience, then developed into problems and their solutions proposed to obtain justification (verification) or assessment in the form of empirical data support in the field[18].

Quantitative research methods can also be interpreted as a research method based on the philosophy of positivism, which is used to examine a particular population or sample, data collection using research instruments, quantitative / statistical data analysis, with the aim to test the hypothesis that has been set[19][18].

This study is research testing its hypothesis to explain the relationship of certain relationships' nature or determine differences between groups with a causality approach. It is a research that wants to find an explanation in the form of a causal relationship between several concepts or several variables or strategies developed in management [20].

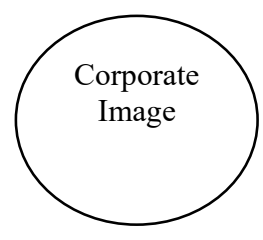




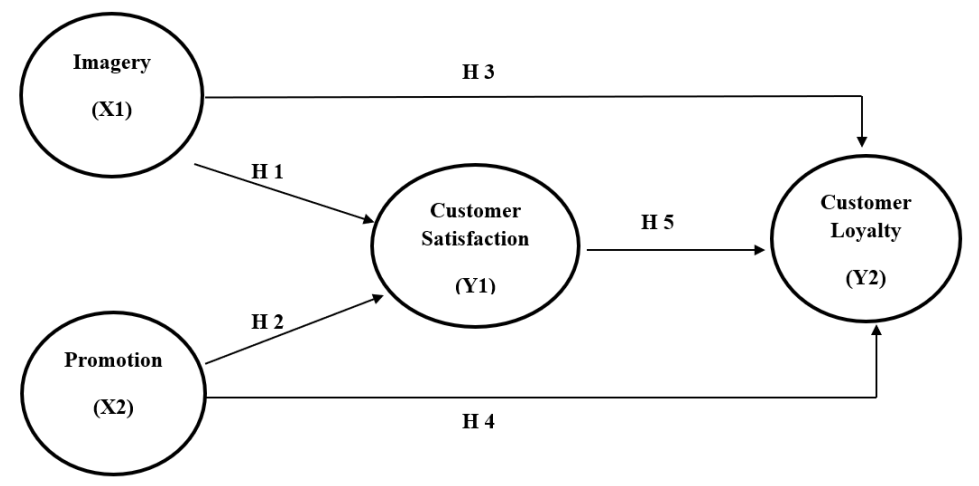

Fig. 1. Research Model and Hypothesis.

In this study, the population is customers who shop at Alfamart in Tangerang. with the following characteristics: 1) at least 17 years old, 2) shop at Alfamart Tangerang more than 2 times within 3 months. In this study the method of data collection used was a questionnaire (list of questions) given to respondents to obtain primary data. a questionnaire is a measurement tool in the form of a list of questions made using a Likert scale of 1-5 to get data that is interval and given a score or value, to be answered more easily by respondents who only provide a mark on a scale of 1-5 already available, where scale 1 means "strongly disagree" and scale 5 means "strongly agree".

\section{Results and Discussions}

In the previous journal entitled the impact of Marketing Mix towards Customer Loyalty Mediated by Customer satisfaction of Blackberry Indonesia showed that all marketing mixed have some significant impact of toward customer loyalty mediated by customer satisfaction. It gives $60.5 \%$ impacts of how marketing mixed give impacts to the customer satisfaction [21].

The second journal was about the influence of corporate image and customers' satisfaction towards consumers' loyalty to traditional foods in Surayaba also concluded that the influence of corporate image gave dominant customer satisfaction in Surabaya thought most of the sellers were not considered it as one of the important tools to use to create customer loyalty [22].

The third journal was about the effect of brand image which affect customers loyalty. In this journal showed that brand image gave a positive impact of how the elements of brand image could give. In other words, it has positive correlations between brand image and customer satisfaction which created customer loyalty [23].

The fourth journal discussed how promotion, brand image, and service quality in promoting the city of Palembang. The result of the journal implies that there are no significant effects on how they prmoto or brand their image to tourists' satisfaction and to the loyalty of the tourist to revisit Palembang. On the other hand, Service quality gave effects to the loyalty of the tourists [24] 
Table 1. State of the Art

\begin{tabular}{ll}
\hline \multicolumn{1}{c}{ Journal Title } & \multicolumn{1}{c}{$\begin{array}{c}\text { Authors and Years } \\
\text { Published }\end{array}$} \\
\hline $\begin{array}{l}\text { The Impact of Marketing Mix towards Customer Loyalty Mediated by } \\
\text { Customer Satisfaction of Blackberry Indonesia } \\
\text { the Influence of Image and Customers'Satisfaction Towards }\end{array}$ & $\begin{array}{l}\text { R. Sukamto and D. B. } \\
\text { Lumintan, 2015 } \\
\text { C.E. Susanti, 2010 }\end{array}$ \\
$\begin{array}{l}\text { Consumers'Loyalty To Traditional Foods in Surabaya } \\
\text { The Effects of Brand Image on Customer Satisfaction and Loyalty }\end{array}$ & R Neupane, 2015 \\
$\begin{array}{l}\text { Intention in Retail Super Market Chain UK } \\
\text { The Effect of Promotion, Service Quality, Brand Image on the }\end{array}$ & S. Rahayu, 2015 \\
$\begin{array}{l}\text { Satisfaction of the Tourists Visiting the City Palembang and the } \\
\text { Implication on Their Loyalty to the Visited Resorts }\end{array}$ & \\
\hline
\end{tabular}

The following will be presented with a general description of respondents who were the object of this study, namely Alfamart minimarket customers in Tangerang. Respondents were taken as a sample are 252 people. The study results showed that from a sample of 252 Alfamart minimarket customers in Tangerang can be obtained an overview of each respondent's work. Based on primary data collected, respondent data obtained were at the age of 17-30 years as many as $198(77.6 \%)$ people; aged $31-40$ years as many as $35(13.9 \%)$ people; aged $41-50$ years as many as $14 \%(5.6 \%)$ people; age more than 51 years as many as 5 (1.9\%) people; female sex as many as 152 people $(60.3 \%)$; and male sex as many as 100 people (39.7\%); having S1 education background as many as 157 people $(62.3 \%)$; - the average shopping in 3 months was more than 3 times as many as 176 people $(69.8 \%)$.

The tendency of respondents in answering the questionnaire was categorized as follows:

Table 2. Descriptive Statistics

Source: Data processed from primary data, 2020

The table showed that the descriptive variable image, promotion, customer satisfaction, and customer loyalty show the number of respondents $(\mathrm{N})$ there were 252 . The minimum value of the image variable was 1.75 , and the maximum value was 5.00 . the minimum value of the promotion variable was 2.00 , and the maximum value was 5.00 . The minimum value was the customer satisfaction variable, and was 1.75 , and the maximum value was 5.00 . The minimum value of the customer loyalty variable was 1.67 and the maximum value was 5.00. The selected values were 0 for no and 1 for yes. The youngest age is 17 years and 51 years old. Gender only consisted of the value 0 for women and 1 for men. The variable meant statistical values, namely image, promotion, customer satisfaction, and customer loyalty, were higher than the Std statistical deviation, which meant there was no significant data variation because the value of the data variation was lower than the average value. At the same time, the mean sex variable was smaller than the standard deviation. This result showed that the variety of data is wide. 
Tabel 3. Validity test

\begin{tabular}{cccc}
\hline \multirow{4}{*}{ Imagery } & Indicator & Loading factor & Information \\
& X1 & 0.636 & Valid \\
& X2 & 0.783 & Valid \\
& X3 & 0.883 & Valid \\
& X4 & 0.786 & Valid \\
& X5 & 0.694 & Valid \\
Promotion & X6 & 0.761 & Valid \\
& X7 & 0.749 & Valid \\
& X8 & 0.604 & Valid \\
& X9 & 0.728 & Valid \\
Customer & X10 & 0.872 & Valid \\
Satisfaction & Y1 & 0.802 & Valid \\
& Y2 & 0.744 & Valid \\
& Y3 & 0.769 & Valid \\
& Y4 & 0.765 & Valid \\
Customer & Y5 & 0.835 & Valid \\
Loyality & Y6 & 0.784 & Valid \\
& Y8 & 0.837 & Valid \\
& Y9 & 0.795 & Valid \\
& Y10 & 0.745 & Valid \\
& Source: Data processed from Primary data, 2020
\end{tabular}

Validity Test was used to show the extent to which a question on a questionnaire was able to express something that will be measured by the questionnaire. This validity test ensures that each question will be classified in the variables that have been determined (construct validity). Validity test for image, promotion, customer satisfaction and customer loyalty variables show that the data variables were valid. This is indicated by the significant number of the total number of indicators $>0.05$, so it can be concluded that each question indicator is valid.

Tabel 4. Reliability Test

\begin{tabular}{ccc}
\hline Variabel & Nilai Cronbachs Alpha & Keterangan \\
\hline Imagery & 0.711 & Reliabel \\
Promotion & 0.719 & Reliabel \\
Customer satisfaction & 0.718 & Reliabel \\
Customer loyalty & 0.711 & Reliabel \\
\hline \multicolumn{2}{c}{ Source: Data processed from Primary data, 2020 }
\end{tabular}

In the output display of image variables, promotion, customer satisfaction and customer loyalty showed that the Cronbachs Alpha value for each variable was between $71.1 \%$ to $72 \%$ which according to the criteria of Nunnally (2006) can be said to be reliable. This was due to Cronbach's alpha $>60 \%$ value, which indicated that respondents answered the questionnaire questions consistently. If the respondent was consistent in answering questions in the questionnaire, then the data will be reliable.

Tabel 5. Regresi Berganda 1

\begin{tabular}{|c|c|c|c|c|}
\hline Model & Unstandardized Coefficients & Standardized Coefficients & $\mathrm{t}$ & Sig. \\
\hline & Std. Error & Beta & & \\
\hline
\end{tabular}




\begin{tabular}{|c|c|c|c|c|c|}
\hline (Constant) & .416 & .340 & & 1.223 & .224 \\
\hline imagery & .333 & .081 & .333 & 4.118 & .000 \\
\hline Promotion & .556 & .091 & .495 & 6.127 & .000 \\
\hline
\end{tabular}

The regression equation had a standardized coefficient of 0.495 for promotion and 0.333 for image. Thus, it can be interpreted that the image and promotion had a positive influence on customer satisfaction. The higher the image and promotion, the more will positively impact the level of customer satisfaction.Promotion had a stronger influence on customer satisfaction compared to image, this was due to the varied promotions offered, competitive prices, information, procedures, overall, frequency of promotion of company value, and product completeness affect customer satisfaction. Therefore, to build customer satisfaction required a high image and promotion.

Table 5. Coefficient of Determination

\begin{tabular}{|c|c|c|c|}
\hline \multirow[t]{2}{*}{ Model } & & \multirow[t]{2}{*}{ Ajusted R Square } & \multirow[t]{2}{*}{ Std. Error of the estimate } \\
\hline & $\mathrm{R}$ & & \\
\hline 1 & .719 & .518 & .25458 \\
\hline
\end{tabular}

The adjusted $\mathrm{R}$ Square value is 0.508 . This meant that the effect of image and promotion on customer satisfaction was $50.8 \%$ or the variation of changes that occur in customer satisfaction can be explained by the image and promotion of $51.8 \%$, while other variables influence $48.2 \%$.

Table 6. Uji F

\begin{tabular}{cccccc}
\hline Model & \multicolumn{3}{c}{} & F & Sig. \\
& Sum of Square & df & Mean Square & & \\
\hline Regression & 6.747 & 2 & 3.373 & 52.048 & .000 \\
$\begin{array}{c}\text { Residual } \\
\text { Total }\end{array}$ & 6.287 & .97 & .065 & & \\
\hline \multicolumn{7}{c}{ a. } & $\begin{array}{c}\text { Predictor (constant): Promotoni, Imagery } \\
\text { b. }\end{array}$ & $\begin{array}{c}\text { Dependent Variable: Customer Satisfaction } \\
\text { Source: Primary data processed in 2020 }\end{array}$ &
\end{tabular}

The calculated $\mathrm{F}$ value of 52,048 with a significant level of 0,000 was far below 0.05 which meant that the image and promotion variables simultaneously affect customer satisfaction variables. This can be interpreted as the appropriate model that included the above research variables (goodness of fit).

Table 7. Multiple Regression 2

\begin{tabular}{|c|c|c|c|c|c|}
\hline \multirow{2}{*}{ Model } & \multicolumn{2}{|c|}{ Unstandardized Coefficients } & \multirow{2}{*}{$\begin{array}{c}\text { Standardized Coefficients } \\
\text { Beta }\end{array}$} & \multirow{2}{*}{$\mathrm{t}$} & \multirow{2}{*}{ Sig. } \\
\hline & B & Std. Error & & & \\
\hline (Constant) & .254 & .266 & & 953 & .343 \\
\hline Imagery & .257 & .083 & .249 & 3.098 & .003 \\
\hline Promotion & .237 & .068 & .256 & 3.469 & .001 \\
\hline Satifactions & .407 & 0.79 & .442 & 5.155 & .000 \\
\hline
\end{tabular}

a. $\quad$ Dependent Variable: Customer Loyality

Multiple regression equation: $\mathrm{Y}_{2}=0,249 \mathrm{X}_{1}+0,256 \mathrm{X}_{2}+0,442 \mathrm{Y}_{1}$ 
This regression equation had a standardized coefficient of 0.249 for imagery; 0.256 for promotion and 0.442 which was customer satisfaction, thus it can be interpreted that the image, promotion, and customer satisfaction have a positive influence on customer loyalty. The higher the influence of image, promotion and customer satisfaction, it will have a positive impact on customer loyalty. The influence of image, promotion and customer satisfaction on customer loyalty was partly because customers are satisfied with the infrastructure, procedures and competition owned by Alfamart minimarket in Tangerang. So to build a customer loyalty, a high level of customer satisfaction was needed.

Table 8. Coefficient of Determination

\begin{tabular}{ccccc}
\hline Model & \multicolumn{3}{c}{ Ajusted R Square } & Std. Error of the estimate \\
\cline { 2 - 3 } & $\mathrm{R}$ & R Square & \\
\hline & .813 & .660 & .650 & .19795 \\
\hline & a. & Prediktor (Constant): Satisfaction, Promotion, Image \\
& & \multicolumn{3}{c}{ Source: Primary data processed in 2020 }
\end{tabular}

The adjusted $\mathrm{R}$ Square value is 0.650 . This meant that the influence of image, promotion and customer satisfaction on customer loyalty is $65 \%$, while the remaining $35 \%$ was influenced by other variables not examined.

Table 9. F tes

\begin{tabular}{cccccc}
\hline Model & \multicolumn{5}{c}{ Table 9. F test } \\
& Sum of Square & df & Mean Square & & Sig. \\
Regression & 7.308 & 3 & 2.436 & 62.167 & .000 \\
Residual & 3.762 & .96 & .039 & & \\
Total & 11.069 & .99 & & & \\
\hline a. & $\begin{array}{c}\text { Predictors (constant): Satisfaction, Promotion, Image } \\
\text { b. Dependent Variable: Customer Loyalty }\end{array}$ \\
\end{tabular}

The calculated $F$ value was 62.17 with a significant level of 0.000 well below 0.05 , which means, that the image, promotion, and customer satisfaction simultaneously influence the customer loyalty variable. This result can be interpreted that the model that included the research variables above was appropriate (goodness of fit).

Hypothesis 1: Citra has a positive effect on customer satisfaction.

The image has a positive effect with beta $=0.333$ and is significant to customer satisfaction ( $\mathrm{p}$ $=0,000<0.05 \%$ ). Thus hypothesis 1 is accepted which states that the image positively and significantly affects customer satisfaction.

Hypothesis 2: Promotion has a significant positive effect on customer satisfaction.

Promotion has a positive effect with beta $=0.495$ and is significant towards customer satisfaction with $(\mathrm{p}=0.000<0.05)$. Thus hypothesis 2 is accepted by stating that promotion has a positive and significant effect on customer satisfaction.

Hypothesis 3: The image has a significant positive effect on the level of customer loyalty. The image has a positive effect with beta $=0,249$ and significant on customer loyalty with ( $\mathrm{p}$ $=0.003<0.05)$. Thus hypothesis 3 is accepted, which states that the image has a positive and significant effect on customer loyalty.

Hypothesis 4: Promotion has a significant positive effect on the level of customer loyalty.Promotion has a positive effect with beta $=0.256$ and is significant towards customer 
loyalty with $(\mathrm{p}=0.001<0.05)$. Thus hypothesis 4 is accepted which states that promotion has a positive and significant effect on customer loyalty.

Hipotesis 5: Customer Satisfaction has a significant positive effect on the level of customer loyalty. Customer satisfaction has a positive effect with beta $=0.442$ and is significant towards customer loyalty with $(\mathrm{p}=0,000<0.05)$. Thus hypothesis 5 is accepted which states that customer satisfaction has a positive and significant effect on customer loyalty.

The researchers saw this journal had similarities to the previous research where promotion and brand logo have positive or significant effects to establish customer loyalty. However, there was a difference finding from previous researchers where in this journal the researchers found that corporate value also gave significant effects on customer satisfaction and how it would become customer loyalty afterwards. In other words, the researchers found similarities and diffences towards the previous researches and this research.

\section{Conclusions}

This study aimed to test, analyze, and determine the effect of image, promotion, and customer satisfaction on customer loyalty in Alfamart minimarket customers in Tangerang. This study used a population and sample of customers who have shopped at Alfamart Tangerang in the last 3 months. The author chose the location for distributing questionnaires in the Tangerang area. This study used a sampling method by distributing questionnaires to 252 Alfamart minimarket customers in Tangerang. Based on the analysis results and discussion described, it can be drawn several conclusions on the hypothesis as follows:

Based on the results of testing hypothesis 1 shows that the image has a positive effect on customer satisfaction can be accepted. The image intentionally needs to be created so that it is positive.

Based on the results of testing, hypothesis 2 shows that promotion had a positive effect on customer satisfaction can be accepted. Promotion was one of the best ways to build relationships with customers, because every customer was looking for the best deal for them in shopping. In general, promotional activities made aim at making customers willing to buy more or direct customers to buy certain products.

Based on the results of testing, hypothesis 3 showed that the image has a positive effect on customer loyalty can be accepted. In the context of consumer relations with sellers, in this case the Alfamart minimarket, when customers feel a higher social benefit, the customer will be more loyal to the seller.

Based on the results of testing, hypothesis 4 showed that promotion had a positive effect on customer loyalty can be received. Promotion can change customer feelings and habits through activities that indirectly stimulate through emotional customer, aiming to maintain customer loyalty. Therefore, promotion had a vital role to communicate the existence and value of products to customers.

Based on the results of testing, hypothesis 5 shows that customer satisfaction had a positive effect on customer loyalty can be accepted. Customer satisfaction is one of several causes for the formation of consumer loyalty. Customer satisfaction or dissatisfaction is the difference or gap between expectations before purchase and performance or results felt after purchase.

This research was based on Resources Based Views, and Market Based Views. Resources Based Views was a concept that views that the key to a company's success comes from the 
characteristics of the company's resources. In this research, this is explained through image and promotion variables. Resources Based Views also saw the importance of in-depth knowledge of customers and their requests. Meanwhile, this research was also based on the concept-oriented towards Market Based Views, namely a strategic view based on the market, with a corporate environment contingent. The environment was seen as a situation that can influence a company's strategic direction that can create corporate value through market forces. Market power can be achieved if the company can provide a level of customer satisfaction and loyalty.

The study results found that partially image, promotion, and customer satisfaction variables proved to have a significant effect on customer loyalty. Building customer loyalty must be considered to increase customer satisfaction because it has a relatively more significant influence than image and promotion. Therefore, in order to increase customer loyalty, Alfamart's management should always focus its business strategy on efforts to improve its image, promotion and customer satisfaction. Increasing customer loyalty can be done in many ways including:

1. Always developed new products so that they were able to meet the needs and desires of customers better than competitors. As a company they need to touch their customers' affection [25]. This condition might be done by adding a variety of products that are currently crowded on the market, so that all consumer segments can shop at Alfamart or make Alfamart their first choice when they want to shop.

2. Increasing the frequency of promotions, with the increasing number of types of promotions run by Alfamart, it was expected that the intensity of consumers in shopping more often and shopping in large quantities.

\section{References}

[1] P. J. Tan and S. Bogomolova, "A descriptive analysis of consumer's price promotion literacy skills," Int. J. Retail Distrib. Manag., vol. 44, no. 12, pp. 1223-1244, 2016, doi: 10.1108/IJRDM-08-2015-0104.

[2] Kumar Anup, "A conceptual model for automation of product dynamic pricing and sales promotion for a retail organization," Kybernetes, vol. 45, no. 3, pp. 490-507, 2016, doi: http://dx.doi.org/10.1108/MRR-09-2015-0216.

[3] U. Ramanathan, N. Subramanian, and G. Parrott, "Role of social media in retail network operations and marketing to enhance customer satisfaction," Int. J. Oper. Prod. Manag., vol. 37, no. 1, pp. 105-123, 2017, doi: 10.1108/IJOPM-03-2015-0153.

[4] D. Grewal, K. L. Ailawadi, D. Gauri, K. Hall, P. Kopalle, and J. R. Robertson, "Innovations in retail pricing and promotions," J. Retail., vol. 87, no. SUPPL. 1, pp. S43-S52, 2011, doi: 10.1016/j.jretai.2011.04.008.

[5] G. Baltas and P. C. Argouslidis, "Consumer characteristics and demand for store brands," Int. J. Retail Distrib. Manag., vol. 35, no. 5, pp. 328-341, 2007, doi: 10.1108/09590550710743708.

[6] F. X. Yang and S. X. Tan, "Event innovation induced corporate branding," Int. J. Contemp. Hosp. Manag., vol. 29, no. 3, pp. 862-882, 2017, doi: 10.1108/IJCHM-09-2015-0512.

[7] D. Grewal, A. L. Roggeveen, and J. Nordfält, “The Future of Retailing,” J. Retail., vol. 93, no. 1, pp. 1-6, 2017, doi: 10.1016/j.jretai.2016.12.008.

[8] C. H. Jin, M. S. Yoon, and J. Y. Lee, "The influence of brand color identity on brand association and loyalty," J. Prod. Brand Manag., vol. 28, no. 1, pp. 50-62, 2019, doi: 10.1108/JPBM-09-2017-1587. 
[9] M. Blut, C. Teller, and A. Floh, "Testing Retail Marketing-Mix Effects on Patronage: A MetaAnalysis," J. Retail., vol. 94, no. 2, pp. 113-135, 2018, doi: 10.1016/j.jretai.2018.03.001.

[10] A. H. de L. Jos Akkermans, "기사 (Article) 와안내문 (Information) [," Eletronic Libr., vol. 34, no. 1, pp. 1-5, 2018.

[11] J. G. Dawes, "Price promotions: examining the buyer mix and subsequent changes in purchase loyalty," J. Consum. Mark., vol. 35, no. 4, pp. 366-376, 2018, doi: 10.1108/JCM-03-20172134.

[12] Kumkum Bharti Rajat Agrawal Vinay Sharma, "Marketing Intelligence \& Planning Article information :," Mark. Intell. Plan., vol. 32, no. 4, pp. 413-435, 2014, doi: 10.1108/02634501011078138.

[13] D. A. Rauch, M. D. Collins, R. D. Nale, and P. B. Barr, "International Journal of Quality \& Reliability Management,” Int. J. Qual. Reliab. Manag. Int. J. Bank Mark. Iss Int. J. Contemp. Hosp. Manag., vol. 32, no. 1, pp. 250-269, 2015.

[14] T. W. L. Krishna Moorthy, Loh Chun T'ing, Seow Ai Na, Chew Tze Ching, Lee Yuin Loong, Lim Sze Xian, "Article information : Corporate image no longer leads to customer satisfaction and," Emeral D Imsight, 2017.

[15] A. T. Vogel and K. Watchravesringkan, "Consumer evaluations of trend imitation: brand equity, consumer attitudes and preference," J. Prod. Brand Manag., vol. 26, no. 5, pp. 516-527, 2017, doi: 10.1108/JPBM-07-2016-1257.

[16] J. T. Bowen and S. L. Chen McCain, "Transitioning loyalty programs: A commentary on "the relationship between customer loyalty and customer satisfaction,"” Int. J. Contemp. Hosp. Manag., vol. 27, no. 3, pp. 415-430, 2015, doi: 10.1108/IJCHM-07-2014-0368.

[17] O. Berezan, A. S. Krishen, S. Tanford, and C. Raab, "Style before substance? Building loyalty through marketing communication congruity," Eur. J. Mark., vol. 51, no. 7-8, pp. 1332-1352, 2017, doi: 10.1108/EJM-06-2015-0314.

[18] R. Farady Marta et al., "Author Compliance in Following Open Journal System of Communication Science in Indonesia," J. Phys. Conf. Ser., vol. 1175, no. 1, p. 3, 2019, doi: 10.1088/1742-6596/1175/1/012222.

[19] K. Simorangkir, R. Marta, and T. Sadono, "Student's Participation in Class: Between Proximity, Teaching Method, and Communication Intensity," ELLIC, no. 20, 2019, doi: 10.4108/eai.27-42019.2285486.

[20] R. F. Marta and A. Suryani, "Dampak Kekuatan Informasi Film Ngenest terhadap Penilaian Komunitas Stand Up Indonesia di Jakarta," J. ASPIKOM, vol. 3, no. 1, p. 77, 2016, doi: 10.24329/aspikom.v3i1.101.

[21] R. Sukamto and D. B. Lumintan, "The Impact of Marketing Mix towards Customer Loyalty Mediated by Customer Satisfaction of Blackberry Indonesia," iBuss Manag., vol. 3, no. 2, p. $323,2015$.

[22] C. E. Susanti, "the Influence of Image and Customers'Satisfaction Towards Consumers'Loyalty To Traditional Foods in Surabaya," J. Manaj. Pemasar., vol. 4, no. 1, p. 9, 2010, [Online]. Available: http://cpanel.petra.ac.id/ejournal/index.php/mar/article/download/18080/17988.

[23] R. Neupane, "The Effects of Brand Image on Customer Satisfaction and Loyalty Intention in Retail Super Market Chain UK," International Journal of Social Sciences and Management, vol. 2, no. 1. pp. 9-26, 2015, doi: 10.3126/ijssm.v2i1.11814.

[24] S. Rahayu, "The Effect of Promotion, Service Quality, Brand Image on the Satisfaction of the Tourists Visiting the City Palembang and the Implication on Their Loyalty to the Visited Resorts," J. Bus. Econ., vol. 6, no. 4, pp. 770-780, 2015, doi: 10.15341/jbe(21557950)/04.06.2015/012.

[25] M. Chinmi, R. F. Marta, C. G. Haryono, J. Fernando, and Jai Kishon Goswami, "Exploring Online News as Comparative Study Between Vendatu at India And RuangGuru from Indonesia In COVID-19 Pandemic," J. Content, Community Commun., vol. 11, p. 168, 2020, doi: 10.31620/JCCC.06.20/13. 